\title{
Response of INM, Spacing and Cycocel on Quality Attributes of Cabbage [Brassica oleracea (L.) var. capitata] in Bundelkhand
}

Harpal Singh ${ }^{1}$, Vinit Kumar²

10.18805/ag.D-5383

\begin{abstract}
Background: The significance of stabilized use of fertilizers is more populous between the farmers to get higher quality of produce. In integrative agricultural system, integrated nutrient management (INM) provide best way to solve numerous issues regarding sustainability, improving quality, boosting yield and keeping good soil fertility in efficient and economical way. Cabbage is one of the most valued crop among cole group vegetables and it is rich in vitamins and minerals like vitamin $A$, vitamin $C$, vitamin $B_{1}$, $B_{2}$ and $B_{3}$, sulphur, phosphorus, calcium, magnesium, iron, potassium, sodium etc.

Methods: Field experiments were conducted to study the effect of vermicompost, inorganic fertilizers and growth retardant (cycocel) with different spacing in cabbage and carried out in factorial randomized block design at Experimental Farm Bundelkhand University, Jhansi (U.P.) during rabi season 2017-18 and 2018-19. Fertilizers with cycocel treatment increases the accumulation of various minerals and vitamins.

Result: Result indicated that quality attributes of cabbage were found to be highest and significant in the treatment where $50 \%$ RDF (Inorganic Fertilizer) + 50\% Organic (vermicompost) were applied at wider crop geometry $(45 \mathrm{~cm} \times 45 \mathrm{~cm}$ spacing) along with spraying of $300 \mathrm{ppm}$ cycocel (growth retardant). Head yield of cabbage was positively correlated with various quality attributes. Application of vermicompost along with inorganic in head of the cabbage. The experimental findings indicated that reduction in the amount of inorganic fertilizer was not detrimental to quality of cabbage while applying the vermicompost in proper amount that is $50 \%$ in combination with inorganic fertilizers. It is evident that integration of vermicompost and inorganic fertilizer at wider spacing under cycocel treatment enhances the quality of cabbage and also sustaining the fertility of soil.
\end{abstract}

Key words: Ascorbic acid, Cabbage, Cycocel, Fertilizer, Vermicompost.

\section{INTRODUCTION}

The significance of stabilized use of fertilizers is more populous among the farmers to get higher quality of produce. Cabbage is one of the most valued crops among cole group vegetables and it is rich in vitamins and mineral like vitamin $A$, vitamin $C$, vitamin $B_{1}, B_{2}$ and $B_{3}$, sulphur, phosphorus, calcium, magnesium, iron, potassium, sodium etc. The aggressive use of inorganic fertilizers has not only contaminated the soil and water but also affect the biospheres and human beings. So to eliminate more of inorganic fertilization, organic farming would be the best alternative. In the diversified farming system, integrated nutrient management under different crop spacing along with growth regulator is the most appropriate approach to solve various issues related to productivity, quality as well as sustainability. Cabbage is well known for its nutritive and health benefits. It has four distinct uses viz. salads, boiling, pickling and sauerkraut. Cabbage is grown during winter as a major vegetable crop and during summer it is taken as a minor crop or intercrop in Uttar Pradesh. This crops being a gross feeder, is always in need of high requirement of nutrients for producing best quality head in cabbage. On the other hand its productivity is very low in spite of showing great potential in the state. In Uttar Pradesh the production of cabbage is around 302.97 thousand MT from an area of 9.06 thousand hectares with the productivity of $33.44 \mathrm{t} / \mathrm{ha}$ (Anonymous, 2017). Therefore, keeping in view, a field
'Department of Horticulture, Bundelkhand University, Jhansi-284 128, Uttar Pradesh, India.

${ }^{2}$ Department of ENV. Science, Bundelkhand University, Jhansi-284 128, Uttar Pradesh, India.

Corresponding Author: Harpal Singh, Department of Horticulture, Bundelkhand University, Jhansi-284 128, Uttar Pradesh, India. Email: harpalhorticulture@gmail.com

How to cite this article: Singh, H. and Kumar, V. (2021). Response of INM, Spacing and Cycocel on Quality Attributes of Cabbage [Brassica oleracea (L.) var. capitata] in Bundelkhand. Agricultural Science Digest. DOI: 10.18805/ag.D-5383.

Submitted: 19-05-2021 Accepted: 07-07-2021 Online: 03-08-2021

experiment was conducted to study the effect of vermicompost, inorganic fertilizers and growth retardant (cycocel) with different spacing on quality of cabbage in Bundelkhand region.

\section{MATERIALS AND METHODS}

The present study was conducted at Experimental Farm Bundelkhand University Jhansi (U.P.) during rabi season 2017-18 and 2018-19.Geographically, the research farm of the university is located at $25.45^{\circ} \mathrm{N}$ latitude and $78.61^{\circ} \mathrm{E}$ longitude at an altitude of $285 \mathrm{~m}$ from mean sea level having a sub-tropical climate. The experiment was laid out in factorial randomized block design (FRBD) with 27 treatment 
combinations and three replications. The treatments comprised of three different factors such as 1 . Cycocel viz. $\mathrm{C}_{1}(0 \mathrm{ppm}), \mathrm{C}_{2}(300 \mathrm{ppm})$ and $\mathrm{C}_{3}(600 \mathrm{ppm}) ; 2$. Fertilizer application viz. $F_{1}(100 \%$ RDF Inorganic Fertilizer 120:80:60 NPK kg/ha), $F_{2}[75 \%$ RDF (Inorganic Fertilizer) $+25 \%$ Organic (Vermicompost)] and $\mathrm{F}_{3}$ [50\% RDF (Inorganic Fertilizer) $+50 \%$ Organic (Vermicompost)]; 3. Plant spacing viz. $\mathrm{S}_{1}(30 \times 30 \mathrm{~cm}), \mathrm{S}_{2}(45 \times 30 \mathrm{~cm})$ and $\mathrm{S}_{3}(45 \times 45 \mathrm{~cm})$. The observation recorded on moisture percentage, dry weight of cabbage head, ascorbic acid (Mukherjee and Chaudhary, 1983), phosphorus (Olsen et al., 1954), calcium (Derderian, 1961), magnesium (Derderian, 1961), chlorophyll A ( $\mu \mathrm{g} / \mathrm{g}$ fresh weight), chlorophyll B and total chlorophyll (losob et al., 2019). All the agronomic practices were followed as per recommendations to the crop. One month old cabbage seedlings of Pusa Drum Head were transplanted in the main field at different spacing. Biometrical observations of five randomly samples were taken from each treatment with standard procedures and techniques. Data recorded were analyzed with the help of statistical programme- STPR- 3 developed by Department of Mathematics and Statistics, College of Basic Science and Humanities, GBPUAT, Pantnagar, Uttarakhand, India.

\section{RESULTS AND DISCUSSION}

The statistically analysed pool data of two year experiments (Table 1) revealed that different levels of integrated nutrient management, crop geometry and cycocel treatments brought out significant response in quality attributes of cabbage. The highest moisture content $(92.56 \%)$ was recorded in treatment $\mathrm{C}_{2} \mathrm{~F}_{3} \mathrm{~S}_{3}$ which was statistically at par with $\mathrm{C}_{3} \mathrm{~F}_{3} \mathrm{~S}_{2}$ while lowest moisture content $(85.39 \%)$ was observed in treatment $\mathrm{C}_{1} \mathrm{~F}_{1} \mathrm{~S}_{2}$. Manure and fertilizers in the form of $50 \%$ vermicompost and inorganic fertilizers $(50 \%$ RDF) at wider spaced geometry make good soil environment that insist the higher uptake of water which ultimately increase the higher percentage of moisture in cabbage head. The results are in the line of findings of Hatano et al. (2003) and Islam (2011). As per dry matter content the inorganic source of fertilizers responded higher dry matter content in cabbage heads irrespective of spacing. Thus the maximum dry matter content $(14.40 \%)$ was observed in treatment $\mathrm{C}_{1} \mathrm{~F}_{1} \mathrm{~S}_{1}$ which was statistically at par with $\mathrm{C}_{1} \mathrm{~F}_{1} \mathrm{~S}_{2}$ and $\mathrm{C}_{1} \mathrm{~F}_{1} \mathrm{~S}_{3}$ while lowest dry matter content $(7.44 \%)$ was recorded in treatment $\mathrm{C}_{2} \mathrm{~F}_{3} \mathrm{~S}_{3}$. Dry matter of head cabbage was markedly enhanced by inorganic fertilizer irrespective of plant spacing under different doses of cycocel treatment. The possible reason for increase in dry matter might be due to more contribution of minerals through the matured leaves and stem for the development of head by supplying higher carbohydrate to head contributing to higher dry matter content. Increase of cycocel dose suppressed gibberellic acid synthesis leading to clear reduction in dry weight. These finding are in the line of the results reported by Sorenson (1999), Loncaric, et al. (2003), Carter et al. (1997) and Choudhary and Choudhary (2005).
On perusal of data in Table 1 revealed that the different levels of integrated nutrient management, crop geometry and cycocel treatments brought out non-significant response in ascorbic acid content in cabbage heads. However, the highest ascorbic acid content was recorded in treatment $\mathrm{C}_{2} \mathrm{~F}_{3} \mathrm{~S}_{3}$ (40.31 mg/100g wet weight) followed by $\mathrm{C}_{2} \mathrm{~F}_{3} \mathrm{~S}_{2}$ whereas, lowest ascorbic acid content $(23.37 \mathrm{mg} / 100 \mathrm{~g}$ wet weight) was found in treatment $\mathrm{C}_{2} \mathrm{~F}_{1} \mathrm{~S}_{1}$. The maximum ascorbic acid content in cabbage was recorded in the treatment having $50 \%$ Vermicompost $+50 \%$ RDF in combination with $300 \mathrm{ppm}$ cycocel at wider crop geometry $(45 \mathrm{~cm} \times 45 \mathrm{~cm})$. This might be due to physiological response of vermicompost with inorganic sources of nutrients for activation of various enzymes and due to more transport of energy to the head. Similar findings were also observed by Mehandran and Kumar (1998), Sharma and Chandra (2003), Upadhyay et al. (2007), Wang et al. (2010) and Rai et al. (2013), in cabbage.

In terms of phosphorus content the highest phosphorus content $(89.82 \mu \mathrm{g} / \mathrm{ml})$ was observed in treatment $\mathrm{C}_{2} \mathrm{~F}_{3} \mathrm{~S}_{3}$ followed by $\mathrm{C}_{3} \mathrm{~F}_{3} \mathrm{~S}_{3}$ and $\mathrm{C}_{3} \mathrm{~F}_{3} \mathrm{~S}_{2}$ while the lowest content was recorded in treatment $\mathrm{C}_{2} \mathrm{~F}_{2} \mathrm{~S}_{1}(40.12 \mu \mathrm{g} / \mathrm{ml})$. The increase in available phosphorus content in plants by combination of vermcompost and RDF under cycocel treatment at wider crop geometry might be attributed to greater mineralization of native soil phosphorus by reducing ability of soil mineral to fix phosphorus and increased its availability through liberation of organic acid. The organic material as a protective covering on sesquioxide reduced the phosphate fixation capacity of soil and hence increased the phosphorus status in plants. The similar finding has also been reported by Sharma et al. (2005).

The highest calcium content (1192.88 $\mu \mathrm{g} / \mathrm{g}$ wet weight) was observed in treatment $\mathrm{C}_{2} \mathrm{~F}_{3} \mathrm{~S}_{3}$ which was found statistically at par with treatment $\mathrm{C}_{3} \mathrm{~F}_{1} \mathrm{~S}_{2}, \mathrm{C}_{3} \mathrm{~F}_{2} \mathrm{~S}_{2}, \mathrm{C}_{1} \mathrm{~F}_{3} \mathrm{~S}_{2}$ $\mathrm{C}_{1} \mathrm{~F}_{3} \mathrm{~S}_{3}, \mathrm{C}_{3} \mathrm{~F}_{3} \mathrm{~S}_{1}$ and $\mathrm{C}_{3} \mathrm{~F}_{3} \mathrm{~S}_{2}$ whereas, lowest content of calcium (614.89 $\mu \mathrm{g} / \mathrm{g}$ wet weight) was noted in treatment $\mathrm{C}_{1} \mathrm{~F}_{1} \mathrm{~S}_{1}$. The higher amount of $\mathrm{Ca}$ observed by the integrated nutrient management through organic and inorganic sources might be due to mineralization of micronutrients in the soils which exerted the more root pressure flow to carry adequate amounts of water-soluble $\mathrm{Ca}$ to the cabbage head. Calcium also helps in formation of new tissue such as meristematic tips, young leaves and often exhibit distorted growth from improper cell wall formation. It is also activating certain enzymes and to send signals that coordinate certain cellular activities. Similar findings were also reported by Kuo et al. (1981), Tetsuo and Sonoda (1981) and Padamwar and Dakore (2010).

The data shown in Table 1 revealed that the different levels of integrated nutrient management, crop geometry and cycocel brought out significant responses for magnesium and chlorophyll content in cabbage. The highest content of magnesium $(0.0497 \mu \mathrm{g} / \mathrm{g}$ wet weight) was recorded in plants treated with $\mathrm{C}_{2} \mathrm{~F}_{3} \mathrm{~S}_{3}$ which was statistically at par with treatments $\mathrm{C}_{1} \mathrm{~F}_{3} \mathrm{~S}_{1}, \mathrm{C}_{1} \mathrm{~F}_{3} \mathrm{~S}_{2}$ and $\mathrm{C}_{2} \mathrm{~F}_{3} \mathrm{~S}_{1}$ whereas, 


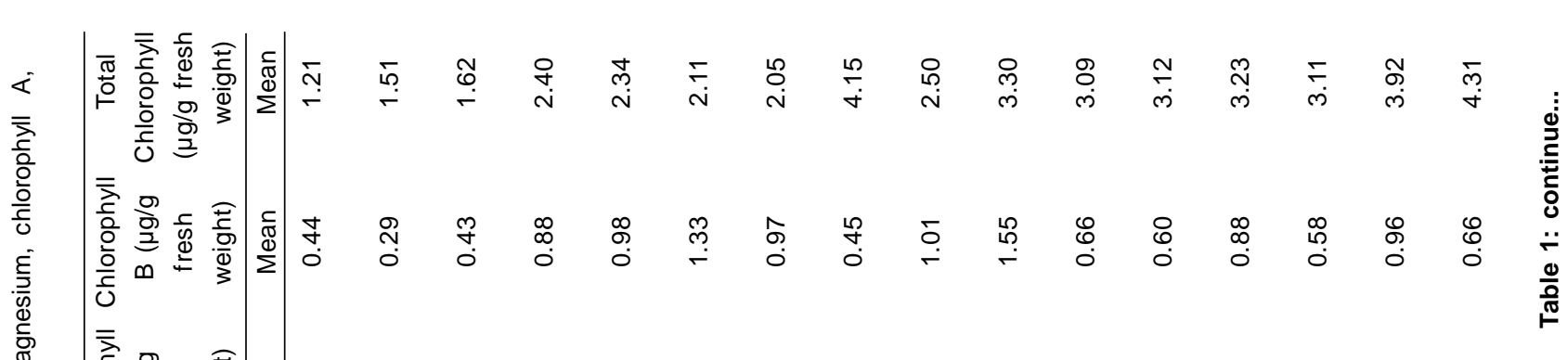



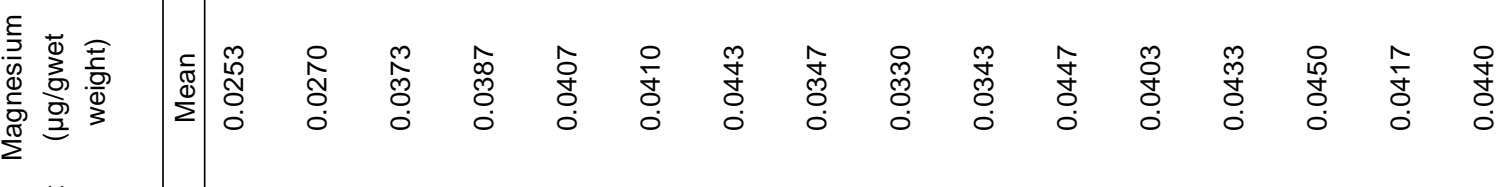

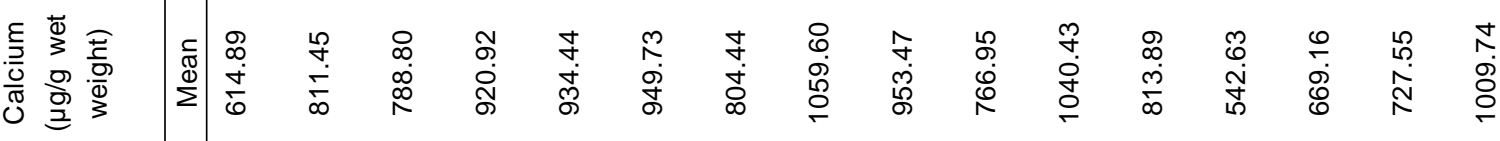

里

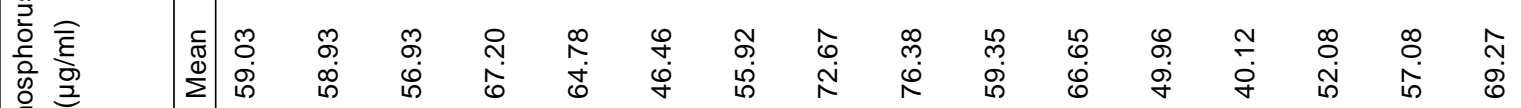
$\frac{c}{\alpha}$

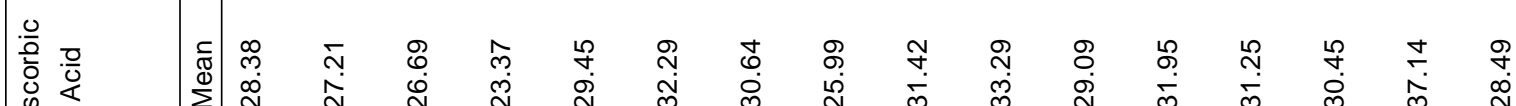

ஓं

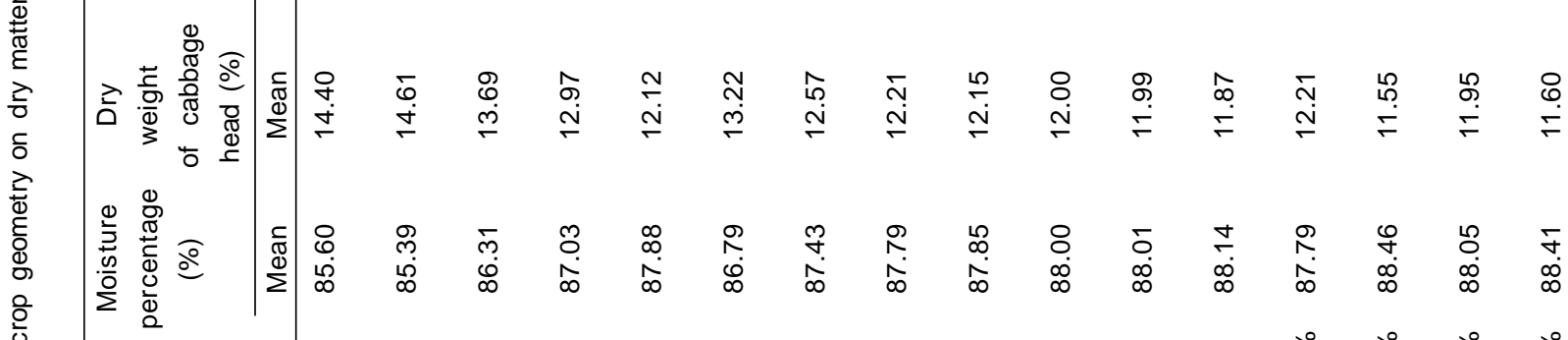




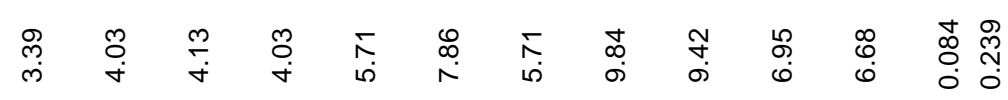

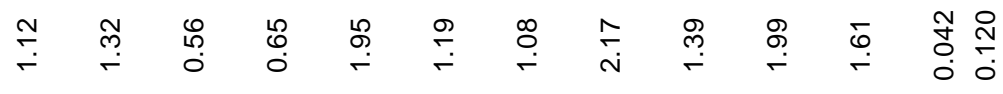

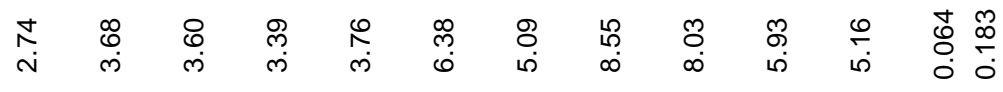

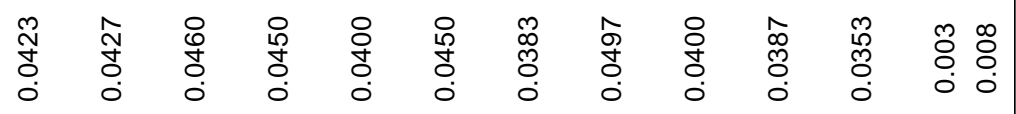

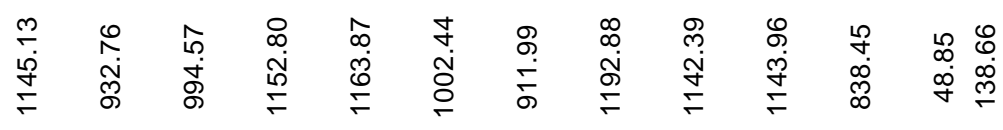

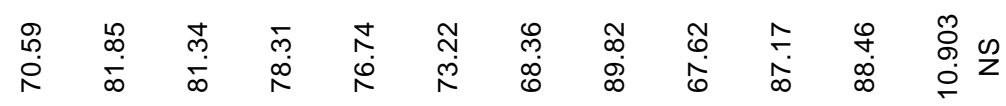

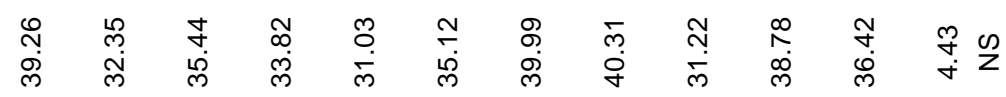

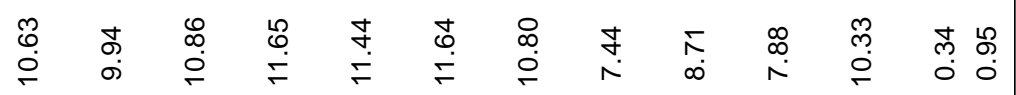

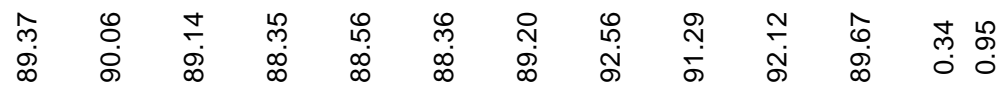

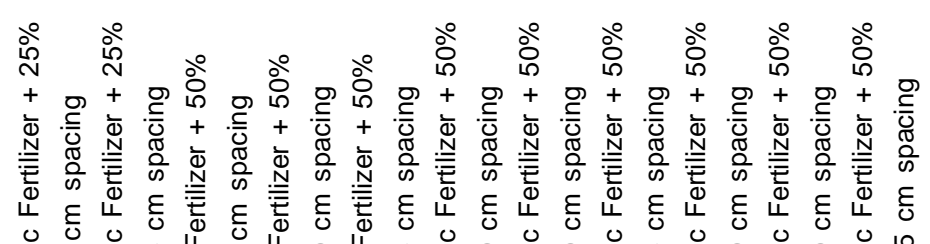

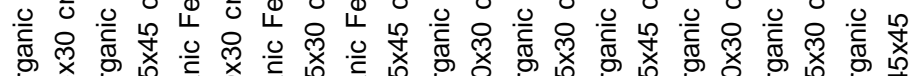

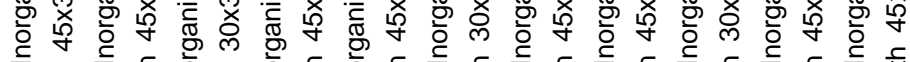

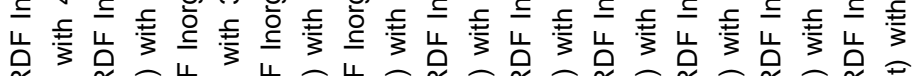

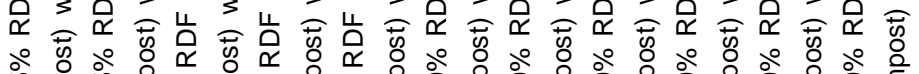

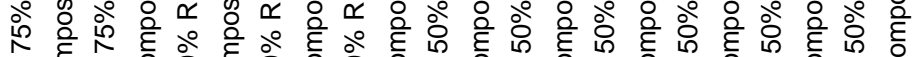
+ o +.0 . U

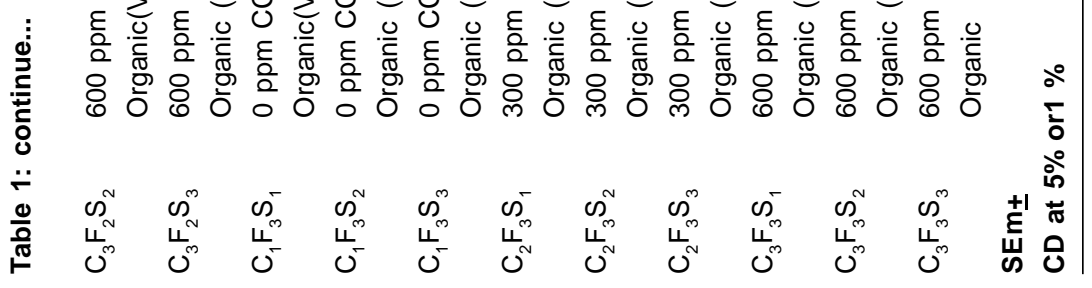


minimum magnesium content was observed in treatment $\mathrm{C}_{1} \mathrm{~F}_{1} \mathrm{~S}_{1}(0.0253 \mu \mathrm{g} / \mathrm{g}$ wet weight). The magnesium content increased positively by the integration of vermicompost and inorganic fertilizers $\{50 \%$ RDF Inorganic Fertilizer $+50 \%$ Organic (vermicompost)\} along with 300 ppm cycocel under wide spaced crop might be due to mineralization of nutrients leading to subsequent uptake of magnesium. It is worth to mention here that $\mathrm{Mg}$ is vital for biosynthesis of chlorophyll and cytochrome led to more activation of the photosystems as well as higher energy transfer from PS-I and PS-II. The increment in magnesium content in plant has positively boosted the relative rate of plant growth. The above findings are in the lines of Balakrishnan et al. (2000), Riga and Anza (2003) and Talat et al. (2014). In terms of chlorophyll content the highest Chlorophyll $A$ content was found in treatment $\mathrm{C}_{2} \mathrm{~F}_{3} \mathrm{~S}_{3}\left(8.55 \mu \mathrm{g} / \mathrm{g}\right.$ fresh weight) followed by $\mathrm{C}_{3} \mathrm{~F}_{3} \mathrm{~S}_{1}$ whereas, lowest content $(0.338 \mu \mathrm{g} / \mathrm{g}$ fresh weight) was recorded in plants treated under $\mathrm{C}_{1} \mathrm{~F}_{1} \mathrm{~S}_{1}$. The highest Chlorophyll $\mathrm{B}$ content $(2.17 \mu \mathrm{g} / \mathrm{g}$ fresh weight) was also observed in treatment $\mathrm{C}_{2} \mathrm{~F}_{3} \mathrm{~S}_{3}$ while the lowest Chlorophyll B content $(0.29$ $\mu \mathrm{g} / \mathrm{g}$ fresh weight) was recorded in treatment $\mathrm{C}_{1} \mathrm{~F}_{1} \mathrm{~S}_{2}$. The increase in chlorophyll $A$ and Chlorophyll $B$ might be due to synergistic effect of organic, inorganic source of nutrients having 50\% RDF (inorganic) $+50 \%$ vermicompost and particularly cycocel treatments which might be delaying the leaf senescence and hence keeping the green pigment from degradation. These results are in agreement with those reported by Emden and Cocks hull (1967) in cabbage.

In terms of total chlorophyll content in different treatments the highest total chlorophyll content $(9.84 \mu \mathrm{g} / \mathrm{g}$ fresh weight) was observed in treatment $\mathrm{C}_{2} \mathrm{~F}_{3} \mathrm{~S}_{3}$ followed by $\mathrm{C}_{3} \mathrm{~F}_{3} \mathrm{~S}_{1}$ and $\mathrm{C}_{2} \mathrm{~F}_{3} \mathrm{~S}_{1}$ while the least amount of total chlorophyll content was found in treatment $\mathrm{C}_{1} \mathrm{~F}_{1} \mathrm{~S}_{1}$. The application of $50 \%$ vermicompost coupled with $50 \%$ inorganic fertilizer along with cycocel treatment under wider crop geometry (45 $\mathrm{cm} \times 45 \mathrm{~cm}$ ) was superior over rest of the treatments. Treatments in which inorganic sources were used without organic fertilizers the chlorophyll content was less. The organic fertilizer in combination with inorganic along with 300 ppm cycocel under wider crop geometry found better for enhancing the chlorophyll content. This might be due to significant enhancement of availability of macro and micro nutrients in the soil, as consequence of which the quality would have been increased. Application of plant growth retardant such as cycocel might have increases the content of cytokinin which resulted in enhancing the amount of leaf chlorophyll. These results are supported with the finding of Chinaswamy and Mariakulandi (1996), Mehaendran and Kumar (1998), Dole and Wilkins (2005) and Rosseni et al. (2005).

\section{CONCLUSION}

It may be concluded from above findings that treatment $\mathrm{C}_{2} \mathrm{~F}_{3} \mathrm{~S}_{3}[300$ ppm CCC + $50 \%$ RDF (inorganic fertilizer) + $50 \%$ Organic (vermicompost) with $45 \mathrm{~cm} \times 45 \mathrm{~cm}$ spacing)] performed best in achieving higher amount of moisture percent, ascorbic acid, phosphorus, calcium and chlorophyll in cabbage as compare to other treatments under the present study. It is evident from the present findings that integration of vermicompost with inorganic NPK fertilizer under wider spacing along with spraying of growth retardant (cycocel) could be beneficial for increasing the qualitative attributes of cabbage and sustaining the fertility status of soil.

\section{ACKNOWLEDGEMENT}

Authors are very thankful to Hon'ble Vice- Chancellor of Bundelkhand University, Jhansi, U.P. and Acadmic coordinator, Institute of Agricultural Sciences, Bundelkhand University campus, Jhansi for providing laboratory and field facilities to carry out the study.

\section{REFERENCES}

Anonymous. (2017). Indian Horticulture Data Base, NHB.

Balakrishnan, K., Rajendren, C. and Kulandaivelu, G. (2000). Differential responses of iron, magnesium, and zinc deficiency on pigment composition, nutrient content, andphotosynthetic activity in tropical fruit crops. Photosynthetica. 38: 477-479.

Carter, J., Singh, B.P., Whiteboard, W. (1997). Growth an development responses of flowering cabbage and kale cultivars to four growth retardants. Hort Science. 32(3): 436-437.

Chinaswamy, K.N. and Mariakulandi, A. (1996). Influence of organic and inorganic manure's on the firmness and storage life of tomato. South Indian Horticulture. 14(1): 36-42.

Choudhary, R.K. and Choudhary, D.N. (2005). Effect of different levels of $\mathrm{N}$ and $\mathrm{P}$ on growth, yield and quality of hybrid cabbage. Haryana Journal of Horticultural Science. 34(1/2): 145-146.

Derderian, M.D. (1961). Determination of Calcium and Magnesium in Plant Material with EDTA. Anal. Chem. 33(12): 17961798.

Dole, J.M. and Wilkins, H.F. (2005). Floriculture. Principles and Species. 2nd ed. Pearson Prentice Hall. New Jersey, USA. pp. 1023.

Emden, H.F.V. and Cockshull, E. (1967). The effect of soil application of (2-Chloroethyl)- trimethyl ammonium chloride on leaf area and dry matter production by the Brussels sprout plant. Journal of experimental Botany. 18(57): 707-715.

Hatano, A., Okawa, H., Imagawa, M. (2003). Effects of the amount of nitrogen application on the nitrate contents of cabbage and Chinese cabbage. Res Bull Aichi-ken Agric Res Center. 35: 79-83.

losob, G.A., Nedeff, V., Prisecaru, M., Cristea, T.O. (2019). Extraction and estimation of chlorophyll content in cabba Seedling leaves (brassica oleracea L. Silviana variety) grown in Soil contaminated with different concentrations of cadmium and copper. Biologie. 28(1): 66-70.

Islam, M.R. (2011). A study of different organic manures on growth and yield of cabbage and their residual effect on stem Amaranth. Thesis M.Sc., Deptt. Horticulture, Bangladesh Agriculture University, Mymensingh, pp. 1-31. 
Kuo, C.G., Tsay, J.S., Tsai, C.L., Chen, R.J. (1981). Tipburn of Chinese cabbage in relation to calcium nutrition and distribution, Scientia Horticulturae. 14(2): 131-138.

Loncaric, Z.T., Teklic, N., Paradjikovic, Jug, I. (2003). Influnce of fertilization an early savoy cabbage yield. Acta Horticulturae. 627: 145-152.

Mehandran, P.P. and Kumar, N. (1998). Effect of organic manure on cabbage cv. Hero (Brassica oleracea L.var. capitata). South zIndian Horticulture. 45 (5-6): 240-243.

Mukherjee, S.P. and Choudhuri, M.A. (1983) Implications of Water Stress-Induced Changes in the leaves of Indigenous Ascorbic Acid and Hydrogen Peroxide in Vigna Seedlings. Physiol. Plant. 58: 166-170.

Olsen, S.R., Cole, C.V., Watanabe, F.S., Dean. L.A. (1954). Estimation of available phosphorus in soils by extraction with $\mathrm{NaHCO}$, USDA Cir.939. U.S. Washington.

Padamwar, S.B. and Dakore, H.G. (2010). Role of vermicompost in enhancing nutritional value of some cole crops. International Journal of Plant Sciences. 5(1): 397-398.

Rai, R., Thapa, U., Mandal, A.R., Roy, B. (2013). Growth, yield and quality of cabbage (Brassica oleracea L.var capitata) as influenced by vermicompost. Environment and Ecology. 3(1): 314-317.

Riga, P. and Anza, M. (2003). Effect of magnesium deficiency on pepper growth parameters. Implications for the determination of Mg-critical value. Journal of Plant Nutrition. 26(8): 1581-1593.

Rossini, P., Rodrigues, A.C., T.D.J.D., Leits, C.I., Barbosa, J.C. (2005). Growth retardants on development and ornamental quality of potted. 'Liliput' Zinnia elegans. JACQ. Scientia Agricola. 62: 337-345.
Sharma, A. and Chandra, A. (2003). Economic evaluation and different treatment combinations of plant spacing and nitrogen in cabbage and cauliflower. Current Agriculture. 26(1/2): 103-105.

Sharma, R., Sharma, S.K., Nandal, T.R. (2005). Effect of different level of nitrogen, phosphorus and potassium on economics of cabbage production. Crop Research Hisar. 30(3): 393398.

Sorensen, J.N. (1999). Nitrogen effect on vegetable production and chemical composition. Acta Horticulturae. 506: 41-59.

Talat, M.A., Tahir, A., lqbal, H.G., Bangroo, S.A., Shabir, U., Rehman, R. and Fozia. (2014). Effect of nitrogen management on quality parameters of cabbage under temperate conditions. Journal of Progressive Agriculture. 5(1): 69.

Tetsuo, H. and Sonoda, Y. (1981). The role of macronutrients in cabbage-head formation. Soil Science and Plant Nutrition. 27(1): 45-54.

Upadhvav, A.K., Singh, J., Singh. J., Bahadur, A. (2007). Effect of biofertilizers in combination of organic amendments or inorganic fertilizers on growth, yield and quality attributes of cabbage (Brassica oleracea L. var. capitata). Asian Journal of Soil Science. 2(2): 138-141.

Wang, D., Shi, Q., Wang, X., Wei, M., Hu, J., Liu, J., Yang, F. (2010). Influence of cow manure vermicompost on the growth, metabolite contents, and antioxidant activities of Chinese cabbage (Brassica campestris spp. chinensis). Biology and Fertility of Soils. 46: 689-696. 